\title{
Prey abundance supporting unusual water mite (Acari: Hydrachnidia) community in a sublacustrine spring and tributary river
}

\author{
IVANA POZOJEVIĆ,, ${ }^{1}$ IVANČICA TERNJEJ, ${ }^{2}$ ZLATKO MIHALJEVIĆ, ${ }^{3}$ \\ SANJA GOTTSTEIN, ${ }^{4}$ NATALIJA VUČKOVIĆ, ${ }^{5}$ VALENTINA DORIĆ, ${ }^{6}$ \\ MARIO RUMIŠEK ${ }^{7}$
}

${ }^{1}$ Division of Zoology, Faculty of Science, University of Zagreb, Rooseveltov trg 6, 10000 Zagreb, Croatia, e-mail: ivana.pozojevic@ biol.pmf.hr

${ }^{2}$ Division of Zoology, Faculty of Science, University of Zagreb, Rooseveltov trg 6, 10000 Zagreb, Croatia, e-mail: ivancica@biol. pmf.hr

${ }^{3}$ Division of Zoology, Faculty of Science, University of Zagreb, Rooseveltov trg 6, 10000 Zagreb, Croatia, e-mail: zlatko.mihaljevic@ biol.pmf.hr

${ }^{4}$ Division of Zoology, Faculty of Science, University of Zagreb, Rooseveltov trg 6, 10000 Zagreb, Croatia, e-mail: sanja.gottstein@ biol.pmf.hr

${ }^{5}$ Division of Zoology, Faculty of Science, University of Zagreb, Rooseveltov trg 6, 10000 Zagreb, Croatia, e-mail: natalija.vuckovic@ biol.pmf.hr

${ }^{6}$ Eko-monitoring d.o.o., Kučanska ul. 15, 42000 Varaždin, Croatia, e-mail: doric.valentina@gmail.com

${ }^{7}$ Independant researcher, Vinogradska 140c, 44320 Kutina, e-mail: rumisek.mario@windowslive.com

Keywords meiofaunal food web, predator-prey interactions, karst water community, sublacustrine spring, karst river

Abstract Water mites are predators on microcrustations (Copepoda, Cladocera, Ostracoda) and insect larvae (mostly Diptera). Their communities usually have great diversity with high species richness but relatively low abundance. This may have important implications for poorly investigated predator-prey interactions of water mites in natural habitats. A sublacustrine karst spring Torak and the mouth of its tributary river Čikola were examined seasonally from August 2016 to June 2017, with the aim of determining water mite distribution connected to prey availability. Triplicate samples were taken with an Ekman dredge on three distinct depth zones (littoral, sublittoral and profundal zone) at both study sites. Both, the karst spring and the tributary river, had typical lentic water mite communities with no rhithrobiont or crenobiont taxa present. Water mite species richness, abundance and alpha diversity were not governed by depth, but rather by prey availability. Greater copepod, ceratopogonid and chironomid abundances were found to positively correlate with higher abundances of water mites. The population of Limnesia connata, previously reported from lime-poor waters exclusively, was most probably supported by vast prey availability, thus unexpectedly surviving in this karst environment. $L$. connata, Neumania vernalis and Piona longipalpis were recorded for the first time in Croatia, while L. connata was recorded for the first time in the Dinaric karst. 
Dostępność pokarmu w źródle krasowym i ujściu rzeki warunkuje występowanie nietypowych zgrupowań wodopójek (Acari: Hydrachnidia)

$\begin{array}{ll}\text { Słowa kluczowe } & \text { sieć pokarmowa w mejofaunie, interakcje drapieżnik-ofiara, zgrupowania wód krasowych, } \\ & \text { źródło na dnie jeziora, rzeka krasowa } \\ \text { Streszczenie } & \text { Wodopójki są drapieżnikami odżywiającymi się mikroskorupiakami (Copepoda, Cladocera, } \\ & \text { Ostracoda) i larwami owadów (głównie Diptera). Ich zgrupowania zazwyczaj charakteryzują } \\ & \text { się dużym zróżnicowaniem gatunkowym, ale stosunkowo niską liczebnością. Może to mieć } \\ & \text { duże znaczenie dla wciąż słabo zbadanych relacji drapieżnik-ofiara w naturalnych siedli- } \\ & \text { skach. Celem badań przeprowadzanych w okresie od sierpnia } 2016 \text { do czerwca } 2017 \text { roku } \\ & \text { w znajdującym się na dnie jeziora, krasowym źródle Torak i ujściu rzeki Čikola było zbadanie } \\ & \text { rozmieszczenia wodopójek w zależności od dostępności pokarmu. Próby pobierano chwyta- } \\ & \text { czem Ekmana w trzech strefach głębokości (litoral, sublitoral i profundal) w obu badanych } \\ & \text { miejscach, za każdym razem wykonując trzy powtórzenia. Zarówno źródło krasowe, jak } \\ & \text { i dopływająca rzeka charakteryzowały się typowo lenitycznym zgrupowaniem wodopójek, } \\ & \text { bez obecności rhithrobiontów i krenobiontów. Bogactwo gatunkowe wodopójek, liczebność } \\ & \text { i wskaźniki różnorodności nie były związane z głębokością, lecz z dostępnością pożywienia. } \\ & \text { Stwierdzono, że większe liczebności widłonogów, ceratopogonidów i chironomidów kore- } \\ & \text { lują dodatnio z większą liczebnością wodopójek. Populacja Limnesia connata, poprzednio } \\ & \text { opisywana wyłącznie z wód ubogich w wapń, była najprawdopodobniej wspierana przez } \\ & \text { ogromną dostępność pokarmu, co niespodziewanie przełożyło się na jej przetrwanie w tym } \\ & \text { krasowym środowisku. L. connata, Neumania vernalis i Piona longipalpis zostały odnotowane } \\ & \text { w Chorwacji po raz pierwszy, natomiast L. connata została po raz pierwszy odnotowana na } \\ & \text { Krasie Dynarskim. }\end{array}$

\section{Introduction}

Predation is a biotic interaction that links water mites to different taxonomic groups and life stages of benthic invertebrate communities (Goldschmidt, 2016). Predatory aquatic adult and deutonymph water mites feed on insect larvae and other small invertebrates (Martin, Stur 2006; Stoch et al., 2011) such as microcrustations (Copepoda, Cladocera, Ostracoda) and insect larvae -mostly Diptera (Martin, 2005; Stoch et al., 2011). Their communities usually have great diversity with high species richness but relatively low abundance (Di Sabatino et al., 2008). This may have important implications for poorly investigated predator-prey interactions of water mites, mostly known from observations and ex-situ studies (Martin, 2005), while the distribution patterns and co-occurrence of water mites and their prey in natural habitats are poorly investigated.

Depth has been shown as an important abiotic driver in water mite composition and structure across lentic habitat profiles (Zawal et al., 2013). Concerning both depth and prey availability, the objectives of this study were: 1) to examine the effect of depth on water mite abundance, species richness and diversity and 2) to examine the dispersal of water mites in connection to prey abundance.

\section{Materials and methods}

\section{Study area}

Torak is a sublacustrine karst spring situated on the southeastern bank of the upstream end of a Lakeland formed by the Čikola river near the Skradinski buk waterfall. The altitude is 
approximately $50 \mathrm{~m}$ above sea level. The submerged spring is circular, having a diameter of about $180 \mathrm{~m}$. The eye of the spring is $47 \mathrm{~m}$ deep and is a tributary of the Čikola River (Figure 1).

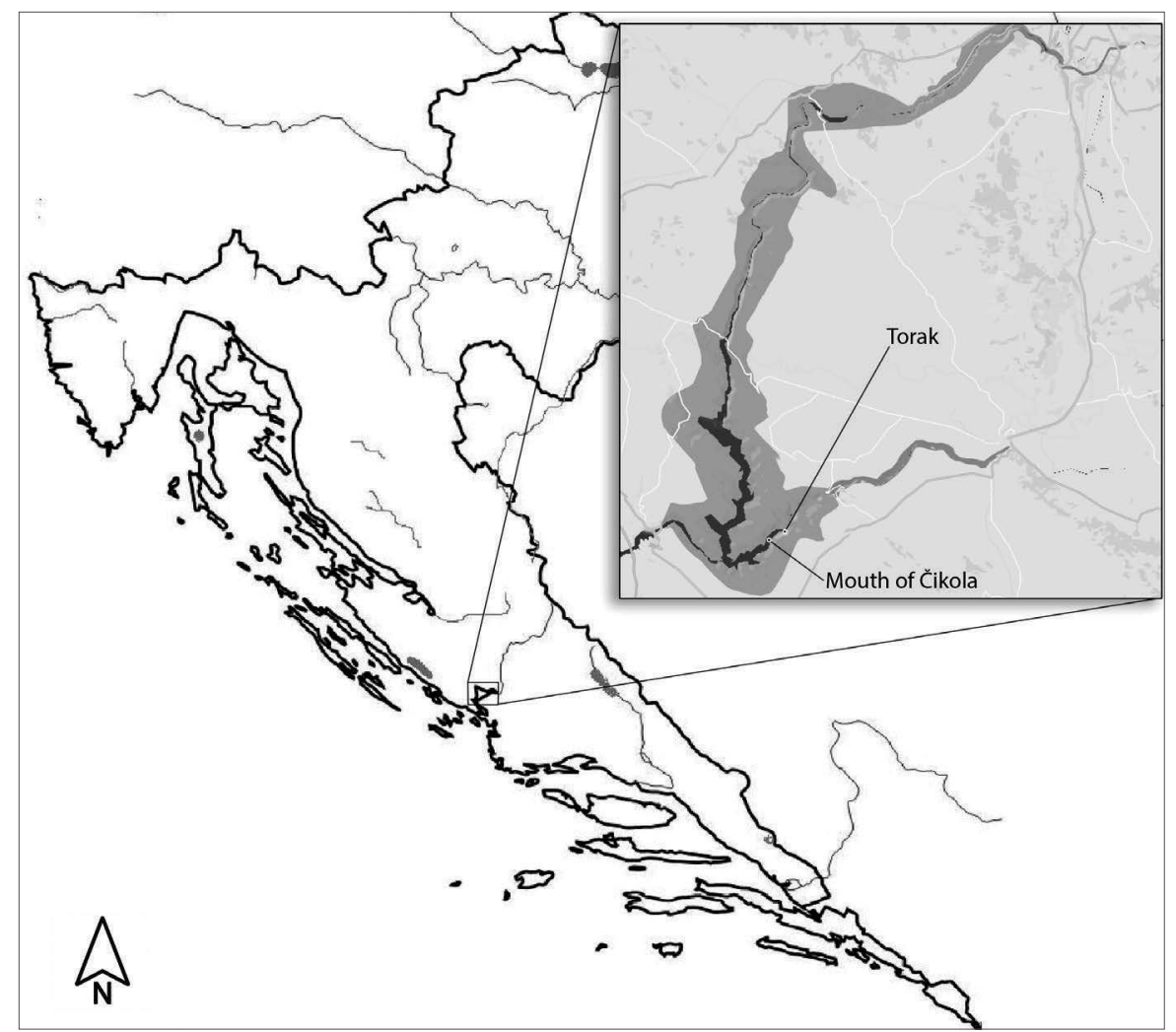

Figure 1. Map of the study area with the locations of the two sampling sites in Krka National Park

The three sampling depths (littoral, sublittoral and profundal zone) were sampled at approximately 2, 10 and 45 meters.

The second sampling site Čikola is a Dalmatian river with the length of $47 \mathrm{~km}$ and is Krka's largest tributary. The Čikola River enters the Krka above Skradinski Buk. The lower reach of the river and the Torak spring lie within the boundaries of Krka National Park (Terzić, Frangen, 2010). At our sampling site, Čikola is at its lowest reach and is very slow flowing, even showing seasonal stratification. The three sampling depths (littoral, sublittoral and profundal zone) were sampled at approximately 2, 10 and 25 meters.

Both sites can be referred to as semi-lentic habitats with some flow present, but with stratification occurring regularly. 


\section{Sampling and laboratory methods}

Each site was sampled four times (once per season) from August 2016 to June 2017. Triplicate samples were taken with an Ekman dredge $(15 \times 15 \mathrm{~cm}$ surface $)$ on three distinct depth zones (littoral, sublittoral and profundal zone) at both sites. In total, we collected 72 benthic macroinvertebrate subsamples (36 from each site). All benthic samples of macroinvertebrate fauna were preserved in $96 \%$ ethyl alcohol. Water mites from the samples were subsequently isolated and fixed in Koenike's solution. All water mite individuals were determined to either species or genus (some deutonymphs) level using general keys by Tuzovskij (1990), Davids et al. (2007), Di Sabatino et al. (2010) and Gerecke et al. (2016). All water mite specimens are deposited at the Department of Biology, Faculty of Science, Zagreb, Croatia. The number of specimens per water mite species were classified as Male/Female/Nymph.

\section{Diversity indices}

The Shannon's (H'), Simpson's (1- $\Lambda$ ), Fisher's and Margalef (d) diversity indices and the Pielou's evenness index (J') were calculated for water mite assemblages at each site using Primer Version 6 software (Clarke, Gorley, 2006).

\section{Data analysis}

We used Pearson's correlation coefficient to determine if a significant correlation could be detected between depth and water mite species richness, abundance and diversity. We used five different indices at each site, as they all have slightly different approaches when calculating alpha diversity.

We used Pearson's correlation coefficient to determine significant correlations between diversity indices and water mite abundance with prey availability.

All values were $\log (x+1)$ transformed before testing. For all tests, $p<0.05$ indicated statistical significance. All statistical analyses were done using Statistica, 13.0 (TIBCO Software Inc., 2017).

\section{Results and discussion}

In total, only thirteen water mite specimens from four taxa were collected during the study period, proving once again the diverse, but not abundant nature of water mite distribution. Both, the karst sublacustrine spring and tributary river, had typical lentic water mite communities with no rhithrobiont or crenobiont taxa present. The most abundant taxon was Neumania vernalis, recorded in both sites with eight specimens found (1/1/6). Arrenurus sp. (0/0/2) and Piona longipalpis $(0 / 1 / 0)$ were found only in Čikola river, while Limnesia connata was found solely in Torak $(1 / 1 / 0)$.

Water mite specimens were not found in the profundal zone. The thermocline, as found by Zawal et al. (2013) seemed to pose an obstacle for water mite colonisation of the deeper layers of our two study sites. However, water mite species richness, abundance and alpha diversity were found not to be governed by depth. Neither specific abundances nor indices based on water mite assemblages were found to correlate with depth significantly (Table 1). 
Table 1. Relationships between water mite species richness, diversity and/or abundance variables and depth. The values of the rank correlations ( $r$ ) and their probabilities (p) for depth variable

\begin{tabular}{|l|r|c|}
\cline { 2 - 3 } \multicolumn{1}{c|}{} & \multicolumn{2}{c|}{ Depth } \\
\cline { 2 - 3 } \multicolumn{1}{c|}{} & $\mathrm{r}$ & $\mathrm{p}$ \\
\hline Hydrachnidia & -0.101 & $>0.05$ \\
\hline Arrenurus sp. & -0.417 & $>0.05$ \\
\hline Limnesia connata & 0.318 & $>0.05$ \\
\hline Neumania vernalis & 0.154 & $>0.05$ \\
\hline Piona longipalpis & 0.036 & $>0.05$ \\
\hline Species richness & -0.062 & $>0.05$ \\
\hline Margalef index & -0.025 & $>0.05$ \\
\hline Pielou evenness & 0.012 & $>0.05$ \\
\hline Fisher index & -0.166 & $>0.05$ \\
\hline Shannon index & -0.073 & $>0.05$ \\
\hline Simpson index & 0.011 & $>0.05$ \\
\hline
\end{tabular}

Greater copepod, total microcrustacean, ceratopogonid and chironomid abundances were found to significantly correlate with higher abundances of water mites, indicating that water mite spatial distribution was governed by prey availably, rather than depth (Table 2).

Table 2. Relationships between prey and water mite abundance. The values of the rank correlations (r) and their probabilities (p) (significant values in bold)

\begin{tabular}{|l|c|c|}
\cline { 2 - 3 } \multicolumn{1}{c|}{} & \multicolumn{2}{c|}{ Hydrachnidia abundance } \\
\cline { 2 - 3 } \multicolumn{1}{c|}{} & $\mathrm{r}$ & $\mathrm{p}$ \\
\hline Chironomidae & $\mathbf{0 . 4 5 0 3}$ & $<\mathbf{0 . 0 5 0}$ \\
\hline Ceratopogonidae & $\mathbf{0 . 6 5 6 5}$ & $<\mathbf{0 . 0 0 1}$ \\
\hline Microcrustacea (all) & $\mathbf{0 . 5 0 6 0}$ & $<\mathbf{0 . 0 1 0}$ \\
\hline Ostracoda & 0.2250 & $>0.050$ \\
\hline Cladocera & 0.2230 & $>0.050$ \\
\hline Copepoda & $\mathbf{0 . 5 1 8 0}$ & $<\mathbf{0 . 0 1 0}$ \\
\hline
\end{tabular}

\section{New records for the water mite fauna of Croatia}

A checklist of water mites in Croatia was published by Pešić (2002), which was later on broadened within the research on water mites of the Balkan Peninsula (Pešić et al., 2010, 2018). These check lists are missing records from Matoničkin and Pavletić (1959) (Woolastookia rotundifrons) and a doctoral thesis from Romana Latiger (1988) in which groundwater water mites were determined by Prof. Schwoerbel (Partnunia angusta, Panisus torrenticolus and Protzia squamosa). These make up a total of 64 water mites recorded in Croatia, and with the current paper three new species are added, making the total number of water mite species found in Croatia 67. 
Limnesia (Limnesia) connata Koenike, 1895

Only two specimens found in the sublacustrine spring confirms the records of van Haaren and Tempelman (2009) who stated that this species is widely distributed, but rather scarce in abundance and is not numerous anywhere. A discrepancy was found with other recordings of the habitat preferences of this species such as: lime-poor waters, quagfens and temporary waters (Schwoerbel, 1956; Smit, van der Hammen, 1996). Two adult specimens (1/1/0) were found in the littoral zone in winter. The population of Limnesia connata, previously reported from lime-poor waters exclusively, was most probably supported by vast prey availability, thus unexpectedly surviving in this karst environment.

Neumania (Neumania) vernalis (Müller, 1776)

In total eight specimens were found (1/1/6) at both sampling sites. The species was found in spring and autumn, in the littoral and sublittoral zone. The findings of Pešić et al. (2007) that stated: "the species is common in eutrophic to dystrophic standing waters" is in slight discrepancy with the findings of this study where the species was found in both the lower reaches of Cikola river and the sublacustrine karst spring Torak, which we consider to be semi-lentic habitats.

Piona longipalpis (Krendowskij, 1878)

This ubiquitous species was found in the sublittoral zone of the slow flowing, lower reaches of Čikola river. Only one specimen was recorded $(0 / 1 / 0)$ in autumn. The species is not habitat specific and is widespread in Europe (Gerecke et al., 2016).

\section{References}

Clarke, K.R., Gorley, R.N. (2006). PRIMER V6: User Manual/Tutorial. Plymouth: Primer-E.

Davids, C., Di Sabatino, A., Gerecke, R., et al. (2007). Acari: Hydrachnidia I. In: I. Bartsch, C. Davids, R. Deichsel et al. (eds.), Chelicerata: Araneae, Acari I. Süßwasserfauna von Mitteleuropa (pp. 241-333), Vol. 7,2-1. Heidelberg: Spektrum Akademischer Verlag.

Di Sabatino, A., Smit, H., Gerecke, R., Goldschmidt, T., Matsumoto, N., Cicolani, B. (2008). Global diversity of water mites (Acari, Hydrachnidia; Arachnida) in freshwater. Hydrobiologia, 595 (1), 303-315.

Di Sabatino, A., Gerecke, R. (2010). Chelicerata: Acari II. In: T. Gledhill, H. Smit (eds.), Süßwasserfauna von Mitteleuropa (pp. 1-216), Vol. 7,2-2. Heidelberg: Spektrum.

Gledhill, T., Pešić, V., Smit, H. (2016). Chelicerata: Acari III. In: R. Gerecke (ed.), Süßwasserfauna von Mitteleuropa (pp. 1-417), Vol. 7,2-3. Heidelberg: Spektrum.

Goldschmidt, T. (2016). Water mites (Acari, Hydrachnidia): powerful but widely neglected bioindicators a review. Neotropical Biodiversity, 2 (1), 12-25.

Lattinger, R. (1988). Ekološka diferenciranost faune podzemnih voda Medvednice. - Doctoral thesis (in Croatian). Zagreb: Sveučilište u Zagrebu.

Martin, P. (2005). Water mites (Hydrachnidia, Acari) as predators in lotic environments. Phytophaga, 307-321.

Martin, P., Stur, E. (2006). Parasite-host associations and life cycles of spring-living water mites (Hydrachnidia, Acari) from Luxembourg. Hydrobiologia, 573 (1), 17-37.

Matoničkin, I., Pavletić, Z. (1959). Životne zajednice na sedrenim slapovima rijeke Une i na brzacima pritoke Unca (Biocenosis on the travertine cataracts in the river Una and in the rapids of the affluent Unac). Musei Macedonici Scientiarum naturalium, 2 (56), 78-99. 
Pešić, V., Gerecke, R., Cîmpean, M. (2007). Water mites of the genus Neumania Lebert (Acari, Hydrachnidia: Unionicolidae: Pionatacinae) in the Mediterranean area. Ann. Limnol. - Int. J. Lim., 43 (3), $187-198$.

Pešić, V. (2002). New records of water mites (Acari, Actinedida) based on the material collected by T. Petkovski from Croatia, including a check-list of species recorded from Croatia. Nat Croat, 11 (4), 447 453.

Pešić, V., Smit, H., Gerecke, R., Di Sabatino, A. (2010). The water mites (Acari: Hydrachnidia) of the Balkan peninsula, a revised survey with new records and descriptions of five new taxa. Zootaxa, 2586, $1-100$.

Pešić, V., Bańkowska, A., Goldschmidt, T., Grabowski, M., Michońki, G., Zawal, A. (2018). Supplement to the checklist of water mites (Acari: Hydrachnidia) from the Balkan peninsula. Zootaxa, 4394, $151-184$.

Schwoerbel, J. (1956). Zur Kenntnis der Wassermilbenfauna des südlichen Schwarzwaldes (Hydrachnellae et Porohalacaridae, Acari). I. Beitrag. Mitt. Bad. Landesver. Naturkunde Naturschutz (Neue Folge), 6, 251-277.

Smit, H., van der Hammen, H. (1996). A remarkable assemblage of water mites in quagfens and carr in The Netherlands (Acari: Hydrachnellae). Ent. Ber., Amst., 56, $28-32$.

Stoch, F., Gerecke, R., Pieri, V., Rossetti, G., Sambugar, B. (2011). Exploring species distribution of spring meiofauna (Annelida, Acari, Crustacea) in the south-eastern Alps. Journal of Limnology, 70 (suppl.), $65-76$.

Terzić, J., Frangen, T. (2010). Hidrogeološka istraživanja vodoopskrbnih zdenaca na krškom izvoru rijeke Čikole. Prvi hrvatski speleološki kongres s međunarodnim sudjelovanjem. Zagreb: Hrvatski speleološki savez.

TIBCO Software Inc. (2017). Statistica (data analysis software system), version 13. Retrieved from: http:// statistica.io.

Tuzovskij, P.V. (1990). Key to Deutonymphs of Water mites. Akademia Nauka UdSSR, Naukau.

van Haaren, T., Tempelman, D. (2009). The dutch species of limnesia, with ecological and biological notes (Acari: Hydrachnidia: Limnesiidae). Nederlandse faunistische mededelingen, 30.

Walter, D.E., Proctor, H.C. (2000). Life at the Microscale: Mites and the Study of Ecology, Evolution and Behaviour. Sydney: New South Wales Press.

Zawal, A., Dzierzgowska, K., Szlauer-Łukaszewska, A., Michoński, G., Kłosowska, M., Bańkowska, A., Stryjecki, R. (2013). A thermocline as an obstacle to the spread of water mites (Acari: Hydrachnidia) across the lake profile. Aquatic Insects: International Journal of Freshwater Entomology, 35 (1-2), $47-61$.

Cite as: Pozojević, I., Ternjej, I., Mihaljević, Z., Gottstein, S., Vučković, N., Dorić, V., Rumišek, M. (2018). Prey abundance supporting unusual water mite (Acari: Hydrachnidia) community in a sublacustrine spring and tributary river. Acta Biologica, 25, 69-75. DOI: 10.18276/ab.2018.25-06. 